\title{
The Hagiographic Programme of the Mosaics in the South Dome of San Marco at Venice
}

\section{John Osborne}

Volume 22, numéro 1-2, 1995

URI : https://id.erudit.org/iderudit/1072511ar

DOI : https://doi.org/10.7202/1072511ar

Aller au sommaire du numéro

\section{Éditeur(s)}

UAAC-AAUC (University Art Association of Canada | Association d'art des universités du Canada)

\section{ISSN}

0315-9906 (imprimé)

1918-4778 (numérique)

Découvrir la revue

Citer cet article

Osborne, J. (1995). The Hagiographic Programme of the Mosaics in the South Dome of San Marco at Venice. RACAR : Revue d'art canadienne / Canadian Art Review, 22(1-2), 19-28. https://doi.org/10.7202/1072511ar

\section{Résumé de l'article}

Les mosaïques du douzième siècle dans l'église de San Marco à Venise ont été le sujet de plusieurs études récentes, notamment celle d'Otto Demus (1984), qui ont essayé d'y trouver un programme intégral. Mais le sens de la décoration de la coupole sud - quatre saints masculins (Nicolas, Clément, Blaise et Léonard), figurés debout, contre un fond d'or - est resté mystérieux, sans rapport évident avec les autres mosaïques à l'intérieur de l'église. Demus les rejette comme une " anomalie ", " la partie de la décoration la plus désappointante ". Cet article proposera, par contre, qu'il existe un élément unifiant, partagé par ces quatre saints, qui peut expliquer leur choix : leur importance au mouvement pour le renouvellement de l'Église, mouvement appelé la Réforme grégorienne (fin du 11e-début du 12e siècle). Tous les quatre sont en vue dans le décor contemporain des églises de Rome (p.e. S. Clemente, S. Maria Immacolata à Ceri), où ils exemplifiaient les qualités importantes au clergé réformateur, notamment l'opposition à l'habitude de simonie et le développement d'un plus grand intérêt porté aux soins pastoraux. Donc, la décoration de la coupole sud peut être interprétée comme une affirmation des intérêts et des activités du mouvement réformateur, et par extension, de l'église romaine. Ce n'est pas par hasard que les premières années du douzième siècle constituent un moment de rapprochement entre Rome et Venise, dont la culmination a eu lieu dans les années 1120 quand la flotte vénitienne a participé aux Croisades, opérant sous le vexille de Saint-Pierre.
Tous droits réservés @ UAAC-AAUC (University Art Association of Canada | Association d'art des universités du Canada), 1997
Ce document est protégé par la loi sur le droit d'auteur. L'utilisation des services d’Érudit (y compris la reproduction) est assujettie à sa politique d'utilisation que vous pouvez consulter en ligne.

https://apropos.erudit.org/fr/usagers/politique-dutilisation/ 


\title{
The Hagiographic Programme of the Mosaics in the South Dome of San Marco at Venice
}

\author{
JoHN OSBORNE, University OF Victoria
}

\begin{abstract}
Résumé
es mosaïques du douzième siècle dans l'église de San Marco à Venise ont été le sujet de plusieurs études récentes, notamment celle d'Otto Demus (1984), qui ont essayé d'y trouver un programme intégral. Mais le sens de la décoration de la coupole sud quatre saints masculins (Nicolas, Clément, Blaise et Léonard), figurés debout, contre un fond d'or - est resté mystérieux, sans rapport évident avec les autres mosaïques à l'intérieur de l'église. Demus les rejette comme une «anomalie», «la partie de la décoration la plus désappointante». Cet article proposera, par contre, qu'il existe un élément unifiant, partagé par ces quatre saints, qui peut expliquer leur choix: leur importance au mouvement pour le renouvellement de l'Église, mouvement appelé la Réforme grégorienne (fin du Ile-début
\end{abstract}

du 12 e siècle). Tous les quatre sont en vue dans le décor contemporain des églises de Rome (p.e. S. Clemente, S. Maria Immacolata à Ceri), où ils exemplifiaient les qualités importantes au clergé réformateur, notamment l'opposition à l'habitude de simonie et le développement d'un plus grand intérêt porté aux soins pastoraux. Donc, la décoration de la coupole sud peut être interprétée comme une affirmation des intérêts et des activités du mouvement réformateur, et par extension, de l'église romaine. Ce n'est pas par hasard que les premières années du douzième siècle constituent un moment de rapprochement entre Rome et Venise, dont la culmination a eu lieu dans les années I 120 quand la flotte vénitienne a participé aux Croisades, opérant sous le vexille de Saint-Pierre
T he mosaics in the dome of the south transept in the church of San Marco at Venice depict the standing figures of saints Nicholas, Clement, Blaise and Leonard, set against a plain gold background (fig. 1). All four saints are identified by Latin inscriptions. These figures have received comparatively little attention in the otherwise ample scholarly literature devoted to this church and to the meaning of its decorative programme. Otto Demus, for example, has dismissed them as "the most astonishing and most disappointing part of the decoration of San Marco"; 1 and they have been similarly all but ignored by Staale Sinding-Larsen, presumably because they could not be easily reconciled with his suggestion that the mosaics of the south transept should be interpreted in relation to the function of that space for the ceremonial entrances of the doge and government from the adjoining Palazzo Ducale. ${ }^{2}$ Both authors make similar statements about the four being "state saints", but neither offers any rationale for their specific choice or placement here. Indeed, Demus seems to find their presence disturbing, an anomaly in an otherwise comprehensive iconographic programme, and comes to the conclusion that "the only possible explanation is artistic bankruptcy, the breakdown of artistic leadership in this part of the church's decoration". "While bearing in mind Sinding-Larsen's caveat that "anything interesting that can said about the twelfth-century system of mosaics in San Marco is extremely hypothetical and will probably remain so for want of documentation", 4 this paper will none the less propose that there does exist a common element which serves to link the four saints in question, and that, consequently, the mosaics of the south dome should be interpreted in the larger context of political and ecclesiastical relations between Venice and the papacy in the first half of the twelfth century.

The construction of the present church of San Marco is thought to have been initiated by Doge Domenico Contarini (1043-70), and completed in the time of Doge Vitale Falier (1084-96)..$^{5}$ Its relationship to earlier structures on the same site remains the subject of considerable scholarly debate, ${ }^{6}$ but this problem has no bearing on the subject at hand. Most of the mosaic decoration of the interior has been assigned to the twelfth century, and attributed in part to mosaicists imported from Constantinople for this purpose, and in part to what Demus calls "the local workshop", who may have been trained as apprentices under the Byzantine team which they subsequently replaced? But, as the same author notes, the surviving documentation is "very meagre", ${ }^{8}$ and the relative chronology remains controversial."

Complicating any discussion is the issue which plagues all studies of medieval mosaics, namely that of restoration, and there is no escaping the fact that large areas of the San Marco decorations have been repaired, and in some instances replaced completely, in subsequent centuries. This must also be the case for the mosaics in the south dome, given the disturbances in the tesserae which are clearly visible in the gold background. In addition, the figure of $\mathrm{St}$ Thecla, one of the four female martyrs who occupy the pendentives beneath the dome, bears the signature of Vincenzo Bastiani and the date of $1512 .{ }^{10}$ But while there is no doubt that the four male saints have at times been restored, probably in the fifteenth century and again in the nineteenth, ${ }^{11}$ there is nothing to suggest that their identities have been changed, nor that there were any additional 
elements in the composition which have subsequently been lost. Consequently, the current configuration may be assumed to reflect the original intention, with the four saints appearing somewhat "awash" in a great sea of golden tesserae. Demus attributes them to the "local workshop" which undertook the general decoration of the choir chapels and transepts, probably in the first half of the twelfth century. ${ }^{12}$

Declining to undertake any analysis of their choice by dismissing them simply as "state saints" is, however, not entirely satisfactory. For one thing, it is not entirely true! While a case can be made for St Nicholas, and possibly also for St Clement, in this regard, Leonard and Blaise have little if any overt connection with Venice, and their cults were never of particular importance in the city. ${ }^{13}$ But surely some rationale must have prompted their choice and the decision to devote an entire dome to their depiction. The underlying currents of meaning which have been found elsewhere in the decorative programme of San Marco, and which characterize medieval church decoration in general, suggest that such decisions were rarely taken whimsically.

There is in fact a common thread which serves to link the four saints in question. Put simply, all were impor-

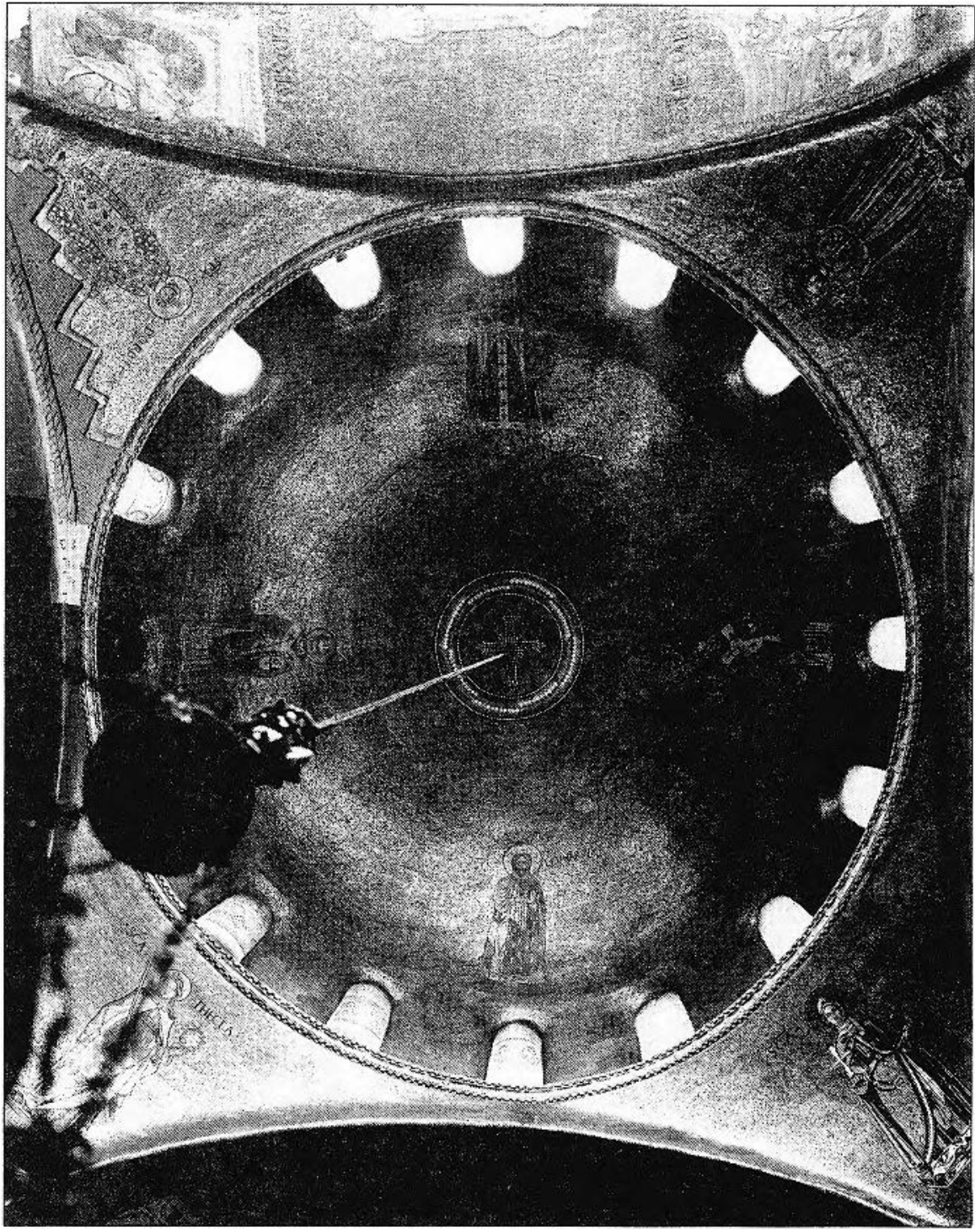

tant to, and had their cults promoted by, the Roman church in the late years of the eleventh and the first quarter of the twelfth century, in conjunction with the movement for ecclesiastical independence and moral renewal known as the Gregorian Reform. ${ }^{14}$ Named for one of its principal papal proponents, Gregory VII (1072-85), this issue dominated ecclesiastical discussions, as well as church-state relationships, for the best part of a century. It is thus no surprise to discover that all four of the south dome saints are also depicted prominently in Roman church decorations executed at this time, in particular those associated with the era of popes Urban II (1088-99), Paschal II (1099-1118) and Calixtus II (1119-24).

The case is perhaps most evident for St Nicholas (fig. 2). Although his cult was known in the west from a comparatively early date, ${ }^{15}$ it received an enormous impetus when his relics were brought from Myra (in south-western Turkey) ${ }^{16}$ to Bari in the year 1087. ${ }^{17}$ The great shrine built to house them became an important site for pilgrimage, and in particular a place where Crusaders stopped to pray before setting sail from Apulia to the Holy Land. No doubt their devotion to Nicholas was due in part to the fortuitous presence of his relics at their point of departure, but also in part to his reputation as a patron of seafarers, and in part to the story which related how he had saved a man named Basil from Saracen captivity. ${ }^{18}$ Clearly he was a good friend to those setting sail to do battle for Christianity in the Middle East.

But the cult was also espoused by Pope Urban II, who in September 1089 travelled to Bari to place the relics officially in their new home with his own hand; and in October 1098 the same pontiff would return to the "corpus 
Figure 2. St Nicholas, detail of south dome of S. Marco, Yenice (Photo: Osvaldo Böhm).

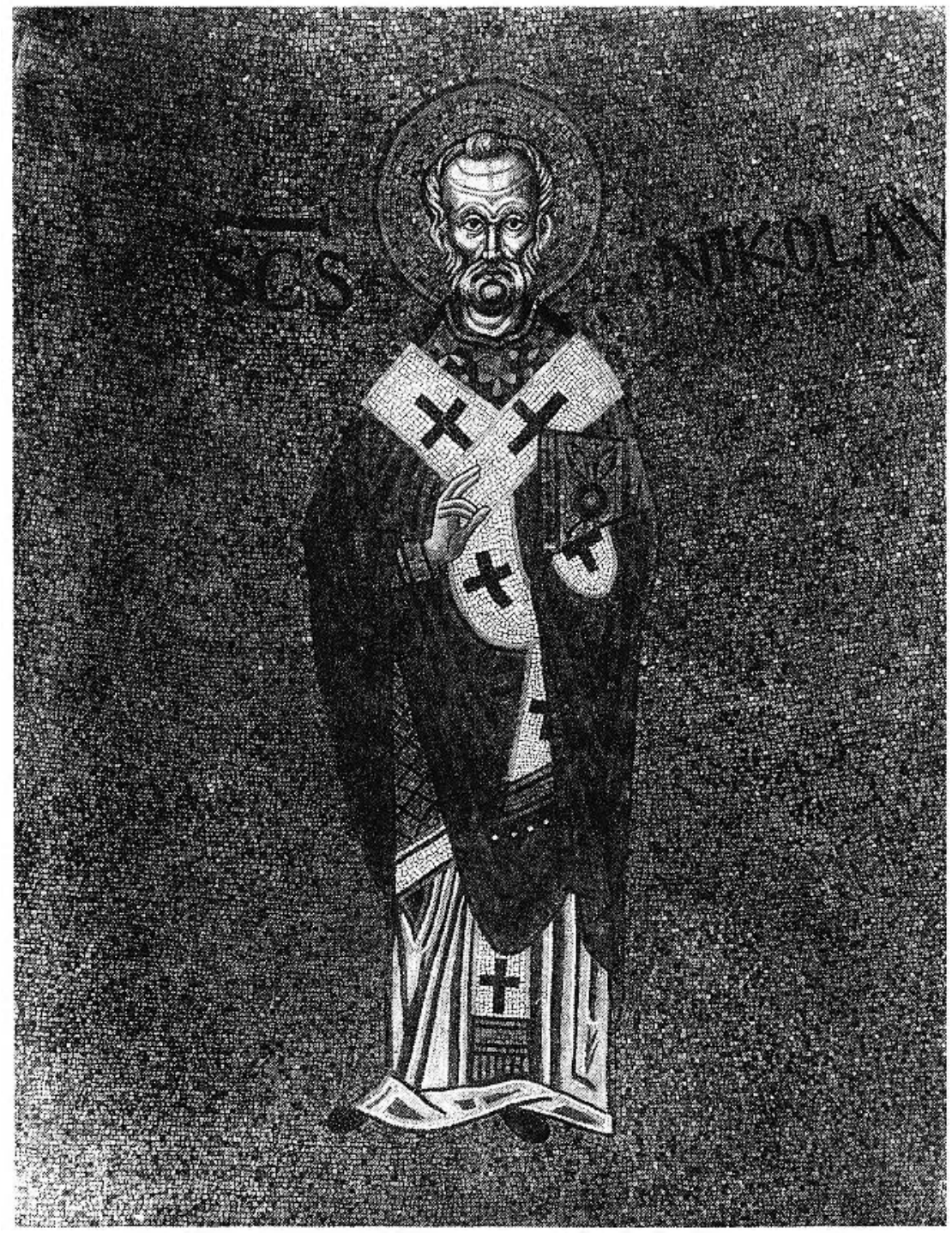

caused him to be adopted as a model for the practice of pastoral care now expected from a bishop. ${ }^{22}$ Whatever the reason, his cult was continued by subsequent pontiffs associated with the Reform movement. In November 1105 Pope Paschal II removed the shrine church at Bari from the jurisdiction of the local archbishop and brought it under the direct authority of the papacy. ${ }^{23}$ Perhaps more significantly, following the Concordat of Worms in 1122, which was viewed by the papacy as a significant victory in its long struggle with the German emperors over the issue of clerical investiture, Pope Calixtus II inaugurated a new papal chapel dedicated to Nicholas in the Lateran palace at Rome. Decorated in the following decade, it featured an image of the saint flanked by the standing figures of eight popes who were closely associated with the Reform movement. ${ }^{24}$

St Clement (fig. 3), an early successor to Peter as bishop of Rome, ${ }^{25}$ was another whose cult was strongly promoted by the Reform papacy. This was probably due in large measure to his writings, both real and attributed, among them the important letter to the church at Corinth, which was considered a canonical text in some early compilations of the Bible (it appears, for example, in the Codex Alexandrinus). Of even greater significance, however, was the pseudo-Clemen-

beati Nicolai", where he convened an important church council attended by 185 bishops. ${ }^{19}$ Urban II appears to have adopted Nicholas as a personal patron saint, and it is worth noting that a church in Rome controlled by the Pierleoni family, his principal supporters in the city, was rededicated by the pontiff to Nicholas at this time. ${ }^{20}$ Also from this period ca. 1100 come two prominent depictions of Nicholas in the mural decorations of Roman churches closely linked with proponents of the Gregorian Reform: the lower church of San Clemente and S. Maria Immacolata at Ceri, the latter located just outside the city to the northwest. ${ }^{21}$ It is not entirely clear why the cult of this saint should subsequently have been adopted more widely by the Reform party in Rome, but such appears to have been the case. It is possible that Nicholas' well-known acts of charity, his redemption of prisoners, and his healing miracles tine Recognitions, which narrated the story of Peter's triumph over Simon Magus and thus constituted an important text for the Reform party's campaign against the practice of simony (the purchase and sale of clerical offices) ${ }^{26}$ Pope Paschal II had served as the titular priest of the Roman church of San Clemente prior to his election to the papacy in 1099 - an election which, significantly, was held in that church; ${ }^{27}$ and the ancient basilica itself was completely rebuilt and lavishly decorated in the early years of the twelfth century, probably at papal instigation and expense. ${ }^{28}$ Even before that rebuilding, probably in the last decade of the eleventh century, the "lower church" of San Clemente was decorated with three large murals depicting events related to the saint: the Mass of St Clement, the miracle of his tomb at Cherson, and the translation of his relics to the shrine church in Rome. ${ }^{29}$ Evidence of 
Figure 3. St Clement, detail of south dome of S. Marco, Venice (Photo: Osvaldo Böhm)

interest in Clement at this time may also be found in the profusion of new texts pertaining to his cult written by the cleric Leo Marsicanus, cardinal bishop of Ostia, including an account of the translation of the saint's relics to Rome which was dedicated to Pope Paschal II. ${ }^{30}$ Of course it was the link to St Peter, and consequently to $\mathrm{St}$ Mark, which also made Clement of interest to the Venetians. ${ }^{31}$ In the church of San Marco the two choir chapels to the left and right of the main apse are dedicated to Peter and Clement respectively, and their twelfth-century mosaics feature a narrative cycle of $\mathrm{St}$ Mark which sets forth the Venetian claim to both spiritual and temporal authority over the upper Adriatic. ${ }^{32}$ But the decorations of the Cappella di $\mathrm{S}$. Clemente also include one episode from the legend of this pope, ${ }^{33}$ and its altar could boast of a relic, ${ }^{34}$ probably acquired in the year 867. ${ }^{35}$ However, Clement's cult in Venice stemmed ultimately from his importance to the see of Rome, an importance which peaked in the early years of the twelfth century.

Of less obvious importance to Venice, but also of interest to the Reform party in Rome, were the cults of saints Blaise and Leonard. Blaise (fig. 4), a fourth-century martyr and bishop

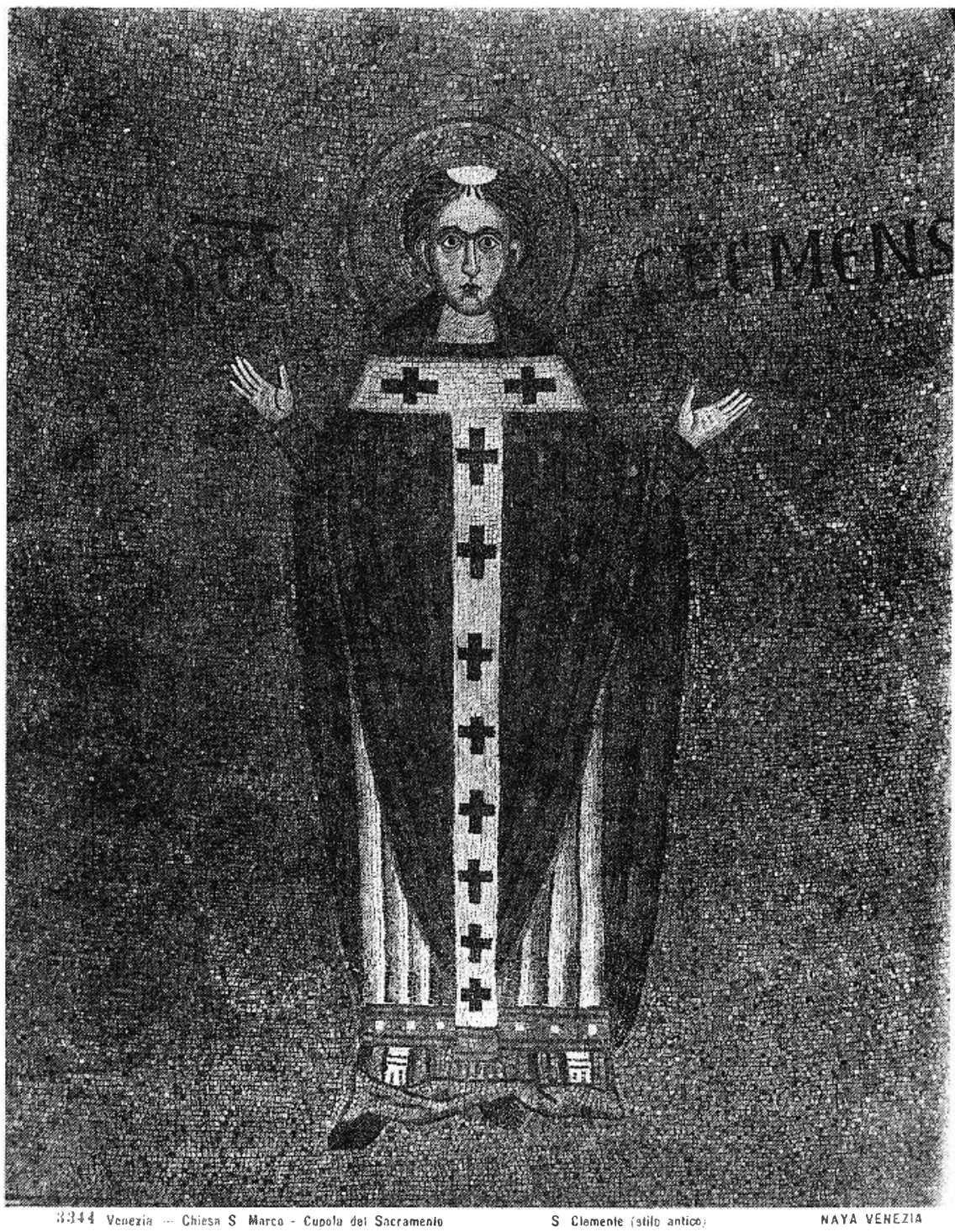
of Sebaste, ${ }^{36}$ was another "model" bishop, famous as a healer, particularly for diseases of the throat, and perhaps also cited in the campaign against simony. ${ }^{37} \mathrm{His}$ veneration was introduced to western Europe at Rome in the midtenth century, ${ }^{38}$ but became particularly important in the second half of the eleventh century, at which time images of Blaise were included in the mural decorations of the atrium of S. Maria Antiqua and the lower church of $S$. Clemente. ${ }^{39}$ Why this interest in his cult should have blossomed remains unknown, but it may possibly be connected to the fact that Blaise was credited with having cured Pope Leo IX (1048-54), one of the primary instigators of the Reform movement, early in his career, prior to his election to the papacy. ${ }^{40}$ At about the same time, the saint's name was introduced prominently into the liturgy of Fonte Avellana, an important centre of monastic renewal. ${ }^{41}$ The

early twelfth century witnessed a profusion of new church dedications to Blaise in the city of Rome, ${ }^{42}$ and at the same time his cult began to spread widely across western Europe. It is undoubtedly significant that scenes from his life were chosen to decorate the apse of the church at Berzé-la-Ville in Burgundy, a possession of the important monastery of Cluny which served as a major focus of the Reform movement. $^{43}$

Of the four figures in the south dome, St Leonard of Noblac (fig. 5), a sixth-century hermit from the area of Limoges in France, ${ }^{44}$ is perhaps the least well known, and he is only rarely found depicted in medieval Italian church decorations. But once again, a significant flurry of interest can be documented in the early years of the twelfth century, related to both Cluniac and papal sponsorship of the reconquista in Spain and the Crusades in the Middle East. 
Figure 4. St Blaise, detail of south dome of S. Marco, Yenice (Photo: Osvaldo Böhm).

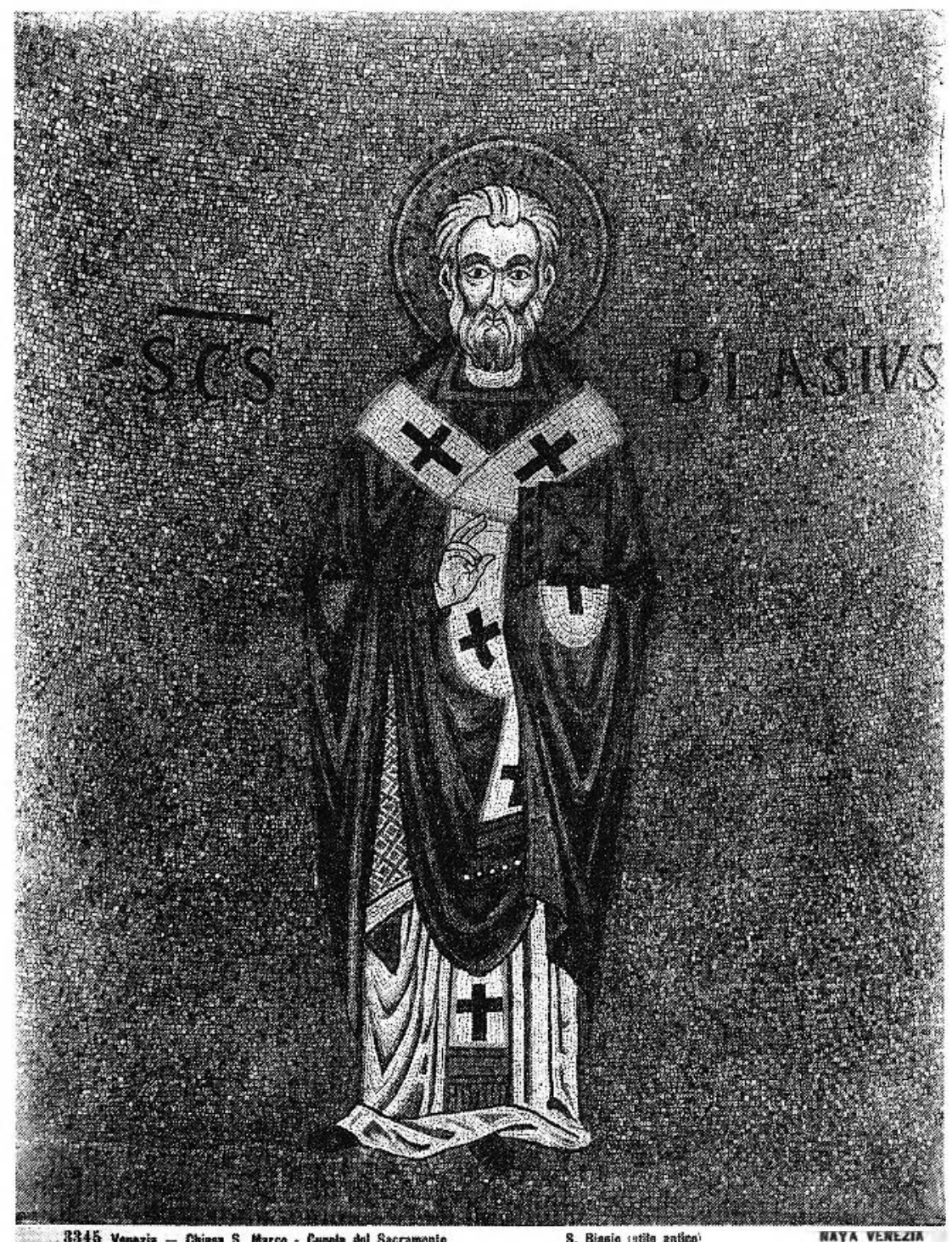

The shrine of St Leonard at Noblac (modern Saint-Léonardde-Noblat) became an important stop on the pilgrimage route across central France from Vézelay to Santiago de Compostela, and is listed as such in the famous twelfthcentury Pilgrim's Guide. ${ }^{45}$ In addition, Leonard became of special interest to a particular category of peregrinus. those who had taken up the cross to fight for Christianity against Islam, for he played an important role as a liberator of prisoners. This aspect of his cult received an enormous boost in the first decade of the twelfth century, when he was credited with having saved one very prominent prisoner, Bohemond of Antioch, who was captured in August 1100 and spent some three years in captivity before being ransomed in 1103 . Returning to Europe to raise a new army, Bohemond actively promoted the cult of St Leonard, and made his own pilgrimage to Noblac in 1106, in order to record his devotion. ${ }^{46}$ While it is not known precisely when the cult of $\mathrm{St}$ Leonard arrived in Italy, his image appears shortly after 1100 in the murals of S. Maria Immacolata at Ceri,${ }^{47}$ a church closely connected to the Reform party in Rome; and from approximately the same period dates the foundation of the abbey of S. Leonardo di Siponto, an important hospice for pilgrims en route to the Holy Land, located near Manfredonia in Apulia. ${ }^{48}$ At San Marco in Venice, in addition to the mosaic in the south dome, the chapel in the east bay of the south transept (now the Cappella del Santissimo Sacramento) was also dedicated to Leonard, perhaps implying the possession of a relic, although none is recorded. A carved relief depicting the standing figure of the saint, datable to the mid-thirteenth century, once stood above the altar of this chapel. It was later moved to the north facade of the church, probably in 1618 when the dedication of the chapel was changed. ${ }^{49}$

Thus, all four saints depicted in the south dome of San Marco can be seen to have had one important aspect in common. In each instance their cult was promoted by the Gregorian Reform movement in the early years of the twelfth century, ${ }^{50}$ a promotion which found tangible expression in the contemporary decoration of churches in Rome and, it would seem, also in Venice. Rather than dismissing the hagiographic programme of the south dome as the unfortunate result of "artistic bankruptcy", let's for the moment assume that the authorities responsible for the decoration of San Marco did have some coherent idea of what they were doing. If so, such a prominent public statement of support for the Reform papacy must surely have been undertaken with full knowledge of its political implications, and thus seems likely to have been produced at a time when Venice enjoyed good relations with Rome. But such was not always the case! What, then, are the implications of the subject matter for the dating of the mosaics in the south dome, and in particular for the general opinion that they should be assigned to the first half of the twelfth century? In order to answer this question, it will first be necessary to examine some of the political and religious fac- 
Figure S. St Leonard, detail of south dome of S. Marco, Yenice (Photo: Osvaldo Böhm).

tors which influenced Venetian state policy.

The movement for ecclesiastic reform which takes its name from Pope Gregory VII was, to a large extent, an outgrowth of the movement for monastic reform which originated in the early tenth century at the Burgundian abbey of Cluny. ${ }^{51}$ In general terms, the doges of Venice could boast of a long history of support for Benedictine monasticism. As early as 819 , less than a decade after the administrative capital of Venetia had been transferred from Malamocco to Rialto, Doge Agnellus Partecipacius (811-27) had assisted in the foundation of the abbey of S. Ilario, located on the mainland at Fusina. ${ }^{52}$ There he and his son Justinian (doge 827-29), as well as three later doges, would be buried. ${ }^{53}$ In the second half of the tenth century, Doge Pietro I Orseolo (976-78) would take this relationship one step further, renouncing his ducal office and travelling to the Cluniac house of SaintMichel-de-Cuxa in the Pyrenees, where he would spend his remaining years as a monk. ${ }^{54}$ In 982, one of his companions in this enterprise, Giovanni Morosini, returned to Venice where he persuaded doge Tribuno Menio to found the important monastery of S. Giorgio Maggiore, facing the Palazzo Ducale across the bacino. ${ }^{55}$ But the lagoon seems to have remained comparatively untouched by the Cluniac reforms until the last years of the eleventh century, when Doge Vitale Michiel (1096-1101) presented the church of SS. Cornelio e Cipriano at Malamocco to the important abbey of S. Benedetto di Polirone, the principal centre of the Reform movement in northern Italy. The political significance of this act should not be underestimated, and it is no surprise that the new foundation grew rapidly in wealth and importance. ${ }^{56}$

The most important "player" in the Gregorian Reform movement was, of course, the papacy itself, and this institution enjoyed particularly strong ties to Cluny in the second half of the eleventh century, culminating with the election of Pope Urban II, a former prior of the Burgundian abbey, in the year 1088. At first glance it might appear that the Venetians would have regarded the papacy as a natural

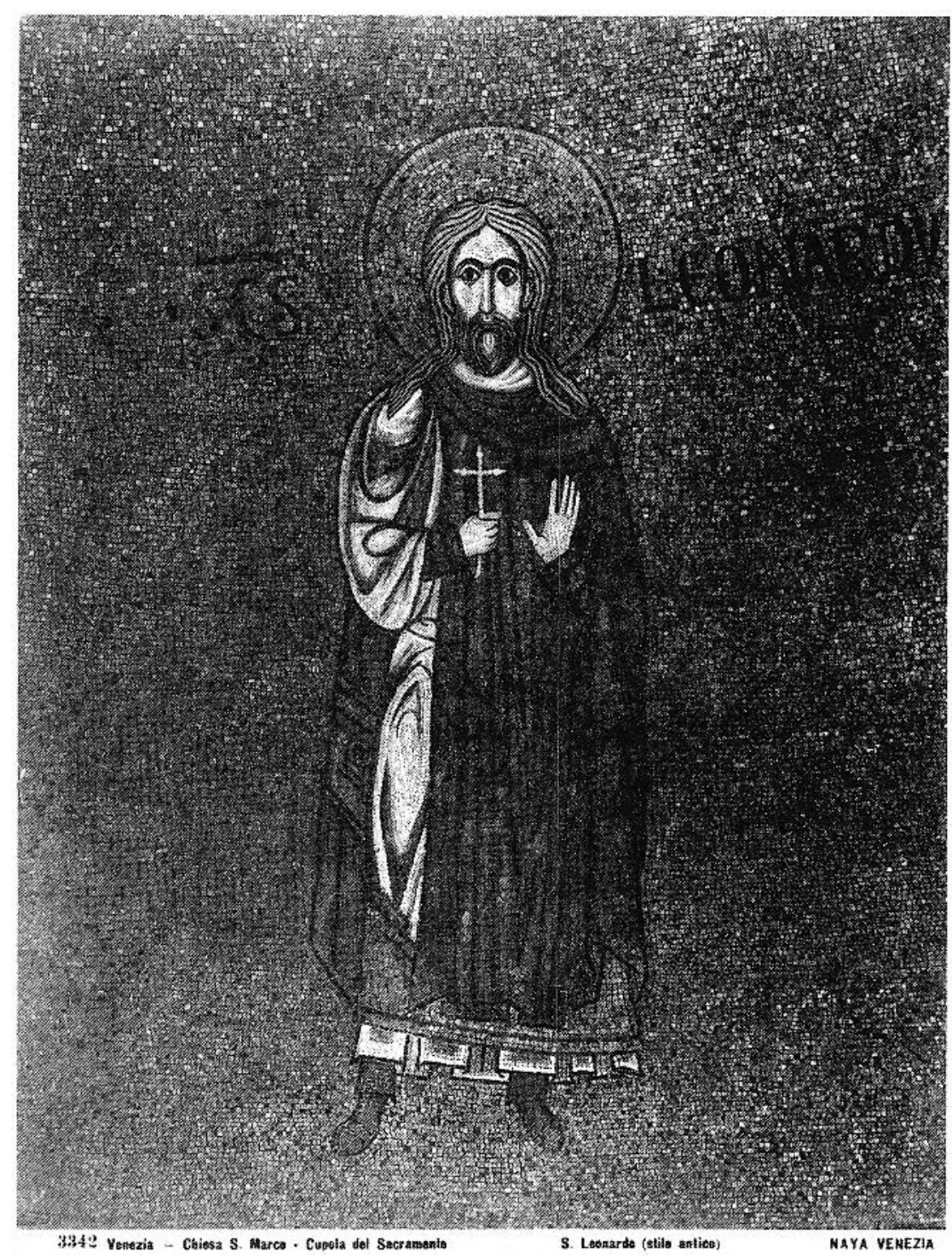

ally in their attempt to thwart the ambitions of the Holy Roman Empire and the patriarchate of Aquileia to dominate the political and ecclesiastical affairs of north-eastern Italy. However, such an alliance was slow to evolve, since for much of the late eleventh century Venice perceived its most significant threat as coming from the Norman adventurers who had occupied southern Italy and Sicily; and in the years 1081-85 the Venetian fleet had joined the forces of the Byzantine emperor Alexios I Komnenos in opposing Norman attempts to secure a foothold on the eastern shore of the Adriatic. ${ }^{57}$ Because popes such as Gregory VII were dependent on Norman support in their own struggle with the German emperors, Venice's atritude toward the papacy remained circumspect. The issue was additionally complicated by the need to constrain the ambitions of the patriarchate of Grado. ${ }^{58}$ Although in 1044 the doge had 
joined with the patriarch in the petition to Pope Benedict IX, on the issue of whether Venetia and Istria should be under the jurisdiction of Grado or of the rival and pro-imperial patriarch of Aquileia, ${ }^{59}$ there was a perceived danger in the former becoming too powerful - and such indeed became the case in the middle of the eleventh century, when the patriarch Domenico Marango, an active member of the Reform movement and close friend of cardinal Humbert of Silva Candida, rose to a position of considerable influence at the papal courts of Leo IX, Nicholas II and Gregory VII. ${ }^{60}$

This chill between Venice and the papacy began to thaw only at the end of the century, under the doge Vitale Michiel (1096-1101) and the patriarch Pietro Badoer (elected ca. 1091), a staunch ally of both the Reform movement and Pope Urban II (1088-99), but also a member of a prominent Venetian family and thus more attuned to the city's political interests than the majority of his predecessors. ${ }^{61}$ An event which was of considerable importance to this process was the First Crusade, preached by Urban II in 1095.62 Against considerable odds, the crusaders had eventually succeeded in reaching their goal, the city of Jerusalem, which fell to their forces in July 1099. Although Venice had at first remained wary of this enterprise, it soon became apparent that more active participation would be profitable both politically and economically, and it seemed unwise to allow commercial rivals such as Pisa and Genoa to gain the advantage. Thus, in the autumn of 1099, a large Venetian fleet set sail for the eastern Mediterranean, commanded by the doge's son, Giovanni Michiel. This expedition is perhaps best known for its claim to have discovered the "authentic" relics of St Nicholas at Myra, although it did reach the Crusader State in the summer of 1100 and assisted in the capture of the city of Haifa. ${ }^{63} \mathrm{~A}$ decade later, in 1110 , a second Venetian fleet, commanded by Doge Ordelaffo Falier, would provide the naval support needed to effect the capture of Sidon. ${ }^{64}$

But the high point of Venetian involvement in the early crusades came in the years 1122-25, significantly at a time when relations with Constantinople had been severely strained by the refusal of the emperor John II Komnenos (1118-43) to renew the trading privileges granted earlier in the chrysobull of his father Alexios. The fleet, commanded by Doge Domenico Michiel (1118-29), won a great victory off the coast at Ascalon in the spring of 1123 and the following year played a major role in the siege and capture of the city of Tyre. In 1125 they returned to Venice triumphant, and bringing more relics, including those of $\mathrm{St}$ Isidore, acquired on the Aegean island of Chios. ${ }^{65}$ Most importantly, however, this had been an official "Crusade", undertaken at the exhortation of Pope Calixtus II (111924), who had sent to the doge the vexillum of St Peter. ${ }^{66}$ Calixtus II was another in the long line of popes who were deeply committed to the principles of the Gregorian Reform. He had been elected in a papal conclave held at the abbey of Cluny, and his pontificate witnessed what was widely perceived at the time as a triumphant victory for the Reform papacy over the German emperors, enshrined in the Concordat of Worms (1122). It may be no coincidence that the same years also witnessed the first appearance in Venice of the "canons regular", the organization of secular clergy reformed along monastic lines which had been established by the Lateran synod of 1059 . Their Venetian canonry of S. Maria della Carità was founded in 1121, by a bull of Calixtus II, and more such houses would follow in the course of the succeeding decades. ${ }^{67}$ The thaw in relations was now complete, and with only a few minor hiccups, Venice would remain on comparatively good terms with the papacy over the next half century, supporting the Lombard League against the German emperor Frederick I, and hosting the "Peace of Venice" in 1177, by which Frederick I and Pope Alexander III brought to an end their eighteen-year schism. ${ }^{68}$

This historical synopsis establishes certain parameters for the dating of any mosaic programme which would be interpreted as promoting the Gregorian Reform, and the related activity of the Crusades. While such a formal expression is unlikely to have been made in the last third of the eleventh century, contemporary with the church's rebuilding, the circumstances of the early decades of the twelfth century appear to have been most propitious for such an enterprise, and perhaps particularly so in the period ca. 1120-25. These years can be regarded as a high point for the fortunes of the Reform papacy, as well as the only moment in Venetian history when its fleet operated under the banner of St Peter. Thus, I venture to suggest that it was not the planners of the south dome decorations who "broke down", to use Demus' term, in devising this deceptively simple programme. Rather, it has been modern art historians, who have failed to appreciate the forceful statement made by the conjunction of these specific saints, a statement which would not have been missed by a politically attuned audience in the twelfth century.

Notes

1 O. Demus, The Mosaics of San Marco in Venice (Chicago, 1984), I, 109.

2 S. Sinding-Larsen, Christ in the Council Hall. Studies in the Religious Iconography of the Venetian Republic (Rome, 1974) [=Acta ad Archaeologiam et Artium Historiam Pertinentia, V], 197-203; 
idem, "A Walk with Otto Demus. The Mosaics of San Marco, Venice, and Art Historical Analysis", Acta ad Archaeologiam et Artium Historiam Pertinentia. Series Altera, VIII (1992), 145 205; and idem, "Chiesa di stato e iconografia musiva", in La Basilica di San Marco: Arte e Simbologia, ed. B. Bertoli (Venice, 1993), 25-45, esp. 38-39.

3 Demus, Mosaics, I, 109

4 Sinding-Larsen, "A Walk with Otto Demus", 148.

5 Cf. O. Demus, The Church of San Marco in Venice (Washingcon, 1960), 70-75.

6 Most recently, for example: J. Warren, "The First Church of San Marco in Venice", The Antiquaries Journal, LXX (1990), $327-$ 59; and R. Mainstone, "The First and Second Churches of San Marco Reconsidered", The Antiquaries Journal, LXXI (1991), 123-37.

7 For an overview, see Demus, Mosaics, I, 278-94.

8 Demus, Mosaics, I, 3.

9 For a recent challenge to Demus' chronology, see E. Hawkins and L. James, "The East Dome of San Marco, Venice: a Reconsideration", Dumbarton Oaks Papers, XLVIII (1994), 229-42.

10 Demus, Mosaics, I, 110.

11 Demus, Mosaics, I, 109-11. See also E. Vio, "L'abside e il transetto: volte e cupole", in O. Demus et al., San Marco, Basilica Patriarcale in Venezia: i mosaici, la storia, l'illuminazione (Milan, 1990), 109-14.

12 Demus, Mosaics, I, 110, 283-84.

13 For example, this is the only Venetian depiction of Leonard listed by G. Kaftal, Iconography of the Saints in the Painting of North East Italy (Florence, 1978), 612-13. Neither Leonard nor Blaise are included in the surviving eleventh-century Venetian saints' calendar: see S. Tramontin, "Il 'Kalendarium' veneziano", in Culto dei Santi a Venezia, ed. S. Tramontin (Venice, 1965), 275327.

14 For a general introduction, see K. Morrison, "The Gregorian Reform", Christian Spirituality: Origins to the Twelfth Century, ed. B. McGinn and J. Meyendorff (London, 1986), 177-93.

15 For Nicholas, see in general Bibliotheca Sanctorum, 12 vols (Rome, 1961-69, repr. 1990), IX, col. 923-48; Lexikon der christlichen Ikonographie, ed. W. Braunfels, 8 vols (RomeFreiburg, 1968-76), VIII, col. 45-58; P. Jounel, Le culte des saints dans les basiliques du Latran et du Vatican au douzième siècle (Rome, 1977), 320-21; and San Nicola di Bari e la sua basilica: culto, arte, tradizione, ed. G. Otranto (Milan, 1987). His cult had reached Rome by the middle of the eighth century, at which time he was depicted in the left aisle of the church of S. Maria Antiqua: cf. J. Wilpert, Die römischen Mosaiken und Malereien der kirchlichen Bautem vom IV. bis XIII. Jahrhundert (Freiburg im Breisgau, 1917), pl. 193-94:1; and W. de Grüneisen, SainteMarie-Antique (Rome, 1911), 543-44.

16 For Myra in the Early Christian and Byzantine periods, see C. Foss, "The Lycian Coast in the Byzantine Age", Dumbarton Oaks Papers, XLVIII (1994), 1-52, esp. 23-37.
17 P. Corsi, "La traslazione delle reliquie", in San Nicola di Bari e la sua Basilica, 37-48. In 1100, thirteen years later, the Venetian fleet would stop at Myra and claim to have found the "real" relics. These were brought back to Venice and placed in the church of S. Nicold al Lido: see D. Nicol, Byzantium and Venice: A Study in Diplomatic and Cultural Relations (Cambridge, 1988), 71-73. For the political context, see also A. Pertusi, "Ai confini tra religione e politica. La contesa per le reliquie di $S$. Nicola tra Bari, Venezia e Genova", Quaderni medievali, V (1978), 6-56. As noted by Nicol (p. 73): "The Venetians were seldom daunted by the facts when they conflicted with the legendary glory of their city."

18 N. Sevcenko, The Life of Saint Nicholas in Byzantine Art (Turin, 1983), 95-103, 143-48.

19 N. Bux, "Il culto e la liturgia", in San Nicola di Bari e la sua Basilica, 49-60. G. Otranto, "San Nicola di Bari", San Nicola di Bari e la sua Basilica, 61-71, esp. 68-69, suggests that the choice of location was deliberate for a Council aimed at restoring Christian unity, since Nicholas was a saint venerated by both the Latin and Greek churches.

20 See C.H. Brakel, "Die vom Reformpapsttum gefördeten Heiligenkulte", Studi Gregoriani, IX (1972), 239-311, esp. 305; and M. Stroll, Symbols as Power. The Papacy following the Investiture Contest (Leiden, 1991), 102. The dedication of S. Nicola in Carcere is recorded in the Liber Pontificalis, ed. L. Duchesne (Paris, 1886-92), II, 294. For this church, see C. Huelsen, Le Chiese di Roma nel Medio Evo (Florence, 1927), 392.

21 See N. Zchomelidse, "Tradition and Innovation in Church Decoration in Rome and Ceri around 1100", Römisches Jahrbuch für Kunstgeschichte, XXX (1995), 7-26, esp. 18, where the links to the Reform movement are stressed. At both sites the identifying inscription spells the saint's name with a " $K$ " (presumably intending a Greek kappa), as is also the case in the south dome of S. Marco.

22 Cf. comments of Bux, "Il culto e la liturgia", 57. G. Constable, "Papal, Imperial and Monastic Propaganda in the Eleventh and Twelfth Centuries", in Prédication et propagande au Moyen Age: Islam, Byzance, Occident, ed. G. Makdisi, D. Sourdel, J. SourdelThomine (Paris, 1983), 179-98, esp. 184 [reprinted in Constable, Monks, Hermits and Crusaders in Medieval Europe (London, 1988), VII], also notes that the saint's namesake, Pope Nicholas I (858-67) "was among the most popular popes of the reform party" because of his numerous letters stressing the authority and independence of the Roman church.

23 The papal bull is preserved in the Archive of the basilica of $\mathrm{St}$ Nicholas at Bari: cf. G. Cioffari, "Dalle origini a Bona Sforza", in San Nicola di Bari e la sua Basilica, 140-73, esp. 143 and fig. 122.

24 For the chapel of St Nicholas, see C.R. Morey, Lost Mosaics and Frescoes of Rome (Princeton, 1915), 64-70; G. Ladner, "Laffresco scomparso nell'abside dell'oratorio di S. Nicola dell'antico palazzo del Laterano" in I Ritratti dei Papi nell'Antichità e nel Medioevo, 3 vols (Vatican City, 1941-84), I, 202-18; and Stroll, Symbols as Power, 132-49. 
25 Bibliotheca Sanctorum, IV, col. 38-48; Lexikon der christlichen Ikonographie, VII, col. 319-23; Jounel, Le culte des saints, 314.

26 See H.E.J. Cowdrey, The Age of Abbot Desiderius. Montecassino, the Papacy, and the Normans in the Eleventh and Early Twelfth Centuries (Oxford, 1983), 83-85.

27 Liber Pontificalis, II, 296.

28 See J. Barclay Lloyd, "The Building History of the Medieval Church of San Clemente in Rome", Journal of the Society of Architectural Historians, XLV (1986), 197-223; and The Medieval Church and Canonry of S. Clemente in Rome (Rome, 1989).

29 Wilpert, Römische Mosaiken und Malereien, pl. 239:2, 240, 241; and J. Osborne, "Proclamations of Power and Presence: the Setting and Function of two Eleventh-Century Murals in the Lower Church of San Clemente, Rome", Mediaeval Studies, LIX (1997), in press.

30 See P. Meyvaert and P. Devos, "Trois énigmes cyrillométhodiennes de la 'Légende Italique' résolues grâce à un document inédit", Analecta Bollandiana, LXXIII (1955), 375-461; and "Autour de Léon d'Ostie et de sa "Translatio S. Clementis", Analecta Bollandiana, LXXIV (1956), 189-240.

31 Cf. B. Bertoli, "Le storie di San Marco nei mosaici e le ragioni dell'agiografia", in La Basilica di San Marco: Arte e Simbologia, ed. B. Bartoli (Venice, 1993), 89-124, esp. 104-07.

32 For the political message of this programme, see T. Dale, "'Inventing' a Sacred Past: Pictorial Narratives of St. Mark the Evangelist in Aquileia and Venice, ca. 1000-1300", Dumbarton Oaks Papers, XLVIII (1994), 53-104, esp. 67-78.

33 Demus, Mosaics, 73-74, pl. 78-79 and fig. 70.

34 As claimed by its inscription; see Demus, Mosaics, 374 n.183.

35 In the mid-ninth century, the relics of St Clement were discovered at Cherson, on the north shore of the Black Sea, the reputed site of his exile and martyrdom, by the Byzantine missionary brothers Cyril and Mechodius. These relics were then brought to central Europe, as part of the mission to Moravia initiated in the autumn of 863, and subsequently taken to Rome, where they were deposited in the church of S. Clemente by Pope Hadrian II. It seems to have escaped the notice of most scholars writing about San Marco that the papal invitation (command?) to go to Rome reached the brothers late in the year 867 in Venice, where they were preparing to embark for their return journey by sea to Constantinople. Clement's relics were still in their possession at this time, and it is not improbable that some portion was donated on that occasion to an altar in the first church of San Marco. For the historical circumstances, see F. Dvornik, Byzantine Missions among the Slavs (New Brunswick, N.J., 1970), 131-37

36 For Blaise: Acta Sanctorum, Febr. I, 331-53; Bibliotheca Sanctorum, III, col. 157-70; Lexikon der christlichen Ikonographie, V, col. 416-19; Jounel, Le culte des saints, 223.

37 Such appears to be a plausible explanation for two episodes from his life, not mentioned in his vita, which were included in the Blaise window at Chartres Cathedral: see J. W. Williams, Bread,
Wine \& Money: The Windows of the Trades at Chartres Cathedral (Chicago, 1993), 134-35.

38 Relics of Blaise were brought to Rome at this time by a community of Greek-speaking nuns from Calabria: see B. Hamilton, "The City of Rome and the Eastern Churches in the Tenth Century", Orientalia Cristiana Periodica, XXVII (1961), 5-26, esp. 11 [reprinted in Monastic Reform, Catharism and the Crusades (900-1300) (London, 1979)]. From the same time comes the earliest mention of a church dedicated to Blaise at Rome, S. Blasii de Penna: see Huelsen, Le Chiese di Roma, 221.

39 For S. Maria Antiqua, see Wilpert, Römische Mosaiken und Malereien, pl. 201:2; and J. Osborne, "The Atrium of S. Maria Antiqua, Rome: a History in Art", Papers of the British School at Rome, LV (1987), 186-223, esp. 216-19. For S. Clemente, see Wilpert, Römischen Mosaiken und Malereien, pl. 239:1; and Zchomelidse, "Tradicion and Innovation", 20.

40 See Sancti Leonis Vita, I, 14 (Patrologia Latina, ed. J.P. Migne, CXLIII, col. 481-83).

41 Patrologia Latina, ed. J. P. Migne, CLI, col. 891, 916, 959.

42 Huelsen, Le Chiese di Roma, 213-23.

43 O. Demus, Romanesque Mural Painting (London, 1970), 41617, and pl. 116-17. For the close connection between Cluny and the Gregorian Reform movement, see note 51 below.

44 For Leonard: Acta Sanctorum, Nov. III, 139-209; Bibliotheca Sanctorum, VII, col. 1198-1208; Lexikon der christlichen Ikonographie, VII, col. 394-98; Jounel, Le culte des saints, 303-04.

45 See A. Shaver-Crandell and P. Gerson, The Pilgrim's Guide to Santiago de Compostela: a Gazetteer (London, 1995), 79-80, 316 17.

46 See A. Poncelet, "Boémond et Léonard", Analecta Bollandiana, XXXI (1912), 24-44.

47 Zchomelidse, "Tradition and Innovation", 20-21.

48 For this ruined abbey, see P. Belli D'Elia, La Puglia (Milan, 1987) [=Italia Romanica, VIII], 363-76; and L. Mongiello, Chiese di Puglia (Bari, 1988), 238-43.

49 See O. Demus, "Zwei marmorne Altarikonen aus San Marco", Jahrbuch der Österreichischen Byzantinischen Gesellschaft, IV (1955), 99-121; and idem, The Church of San Marco, 139. The mosaic scenes in the south transept depicting events from Leonard's vita date from about 1650 (Demus, Mosaics, 13), but may reflect earlier models now lost.

50 For the more general use of saints' cults to promote the values of the Gregorian Reform, see Brakel, "Die vom Reformpapsttum gefördeten Heiligenkulte"; Constable, "Papal, Imperial and Monastic Propaganda", 183-84; V. Pace, "Riforma della chiesa e visualizzazione della santità nella pittura romana: i casi di Sant'Alessio e di Santa Cecilia", Wiener Jahrbuch fur Kunstgeschichte, XLVI/XLVII (1993/94), 541-48; and W. Telesko, "Ad vitam aeternam pervenire exoptamus' - zur 'Renaissance' der Martyriumsfrömmigkeit in der Kunst der 'Gregorianischen Reform'", Festschrift für Hermann Fillitz zum 70. Geburtstag (Cologne, 1994), 163-72. 
51 Cf. R. Morghen, "Monastic Reform and Cluniac Spirituality", in Cluniac Monasticism in the Central Middle Ages, ed. N. Hunt (London, 1971), 11-28; and H.E.J. Cowdrey, The Cluniacs and the Gregorian Reform (Oxford, 1970).

52 The document recording the ducal donation is published in Documenti relativi alla storia di Venezia anteriori al mille, ed. $\mathrm{R}$. Cessi, 2 vols (Padua, 1942; repr. 1991), I, 71-75, no. 44. The site of the abbey was excavated 1873-1885; for the remains, see F. Forlati, "Da Rialto a S. Ilario", in Storia di Venezia. II: Dalle origini del ducato alla IV crociera (Venice, 1958), 623-72, esp. 638-40; and G. Lorenzoni, "Espressioni d'arte: i principali monumenti architettonici”, in Storia di Venezia. I: Origini-Età Ducale, ed. L. Cracco Ruggini et al. (Rome, 1992), 865-91, esp. 865-71

53 A. Da Mosto, I Dogi di Venezia con particolare riguardo alle loro tombe (Venice, 1939), 36-37, speaks of S. Ilario as "una specie di Pantheon".

54 A. Dandolo, Chronica per Extensum Descripta, ed. E. Pastorello (Bologna, 1938) [=Rerum Italicarum Sciptores XII, 1], 184; B. Hamilton, "S. Pierre Damien et les monuments monastiques de son temps", Studi Gregoriani, X (1975), 175-202, esp. 181 82; S. Tramontin, "Problemi agiografici e profili di santi", in La chiesa di Venezia nei secoli XI-XIII, ed. F. Tonon (Venice, 1988), 153-77, esp. 155-60.

55 A. Dandolo, Chronica, 185.

56 See A. Dandolo, Chronica, 223-24. For the document recording the 1098 donation, see V. Lazzarini, "Originali antichissimi della cancelleria veneziana", in Scritti di Paleografia e Diplomatica (rev. ed. Padua, 1969), 158-82, esp. 177-79. The context is discussed by G. Spinelli, "I monasteri benedetrini fra il 1000 ed il 1300", in La chiesa di Venezia nei secoli XI-XIII, ed. F. Tonon (Venice, 1988), 109-33, esp. 111-13. It is interesting to note that, as a result, the names of the doge and his son were entered in the Liber vitae of the monastery of S. Benedetto (ibid., 130 n.22). For the importance and influence of $\mathrm{S}$. Benedetto di Polirone, see Cowdrey, The Cluniacs and the Gregorian Reform, 249-50; and $\mathrm{H}$. Schwarzmaier, "The Monastery of St. Benedict, Polirone, and its Cluniac Associations", in Cluniac Monasticism in the Central Middle Ages, ed. N. Hunt (London, 1971), 123-42.

57 For a succinct summary of events, see Nicol, Byzantium and Venice, 55-59.
58 The various issues influencing relations between Venice and the papacy are discussed in C. Violance, "Venezia fra papato e impero nel secolo XI", Storia della civiltà veneziana. I: Dalle origini al secolo di Marco Polo, ed. V. Branca (Florence, 1979), 139-58.

59 Violante, "Venezia fra papato e impero", 144-45.

60 Violante, "Venezia fra papato e impero", 147-49; G. Cracco, "Chiesa e istituzioni civili nel secolo della quarta crociata", in La chiesa di Venezia nei secoli XI-XIII, ed. F. Tonon (Venice, 1988), 11-30, esp. 13.

61 Violante, "Venezia fra papato e impero", 154-55; Cracco, "Chiesa e istituzioni civili", 13-14.

62 For the Cluniac role, see H.E.J. Cowdrey, "Cluny and the First Crusade”, Revue Bénédictine, LXXXIII (1973), 285-311 [reprinted in Popes, Monks and Crusaders (London, 1984), XV].

63 A. Dandolo, Chronica, 221-23; Nicol, Byzantium and Venice, 68-74.

64 A. Dandolo, Chronica, 228; Nicol, Byzantium and Venice, 75.

65 A. Dandolo, Chronica, 232-35; Nicol, Byzantium and Venice, 78-80.

66 P.F. Kehr, Italia Pontificia (repr. Berlin, 1961), VII, 2: 21, nos. 38-39; A. Dandalo, Chronica, 232; J. Riley-Smith, "The Venetian Crusade of 1122-24", in I comuni italiani nel regno crociato di Gerusalemme, ed. G. Airaldi and B. Kedar (Genoa, 1986), 337 50. A century and a half after the event, Martin da Canal recorded the pope's request as having come "from a father to his son" ("com pere doit envoier a son fis"): Martin da Canal, $L a$ Cronique des Veniciens, ed. F.L. Polidori (Florence, 1845) [=Archivio Storico Italiano, VIII, 229-766], 302. Throughout his text, Da Canal refers to Venice's obedience and service to the "Sainte Yglise", reflecting the general state of good relations over the twelfth and thirteenth centuries. On this point see also Dale, "Inventing' a Sacred Past", 101.

67 Sce A. Fabris, "Esperienze di vita communitaria: i canonici regolari", in La chiesa di Venezia nei secoli XI-XIII, ed. F. Tonon (Venice, 1988), 73-107, esp. 76.

68 A. Dandolo, Chronica, 262-65. Venice would claim that the peace had been secured largely through their efforts, and that the various honours and items of regalia presented to the doge by pope Alexander III had been in recognition of this; see also Sinding-Larsen, Christ in the Council Hall, 158. 